умовою іiі сталого розвитку, повноцінного входження у європейську і світову економіку та освітній простір. Все вищесказане актуалізує дослідження теорії і практики європейської і світової регіональної освітньої політики на прикладі міст і регіонів, що навчаються. Попри доволі грунтовне теоретичне опрацювання концептуальних засад регіональної освітньої політики практика ії впровадження вказує на низку невирішених на сьогодні питань, серед яких - використання інструментів моніторингу прогресу у побудові міста, що навчається. У публікації висвітлено результати дослідження інструментарію моніторингу побудови міст, що навчаються. Запровадження концепції міста, що навчається, передбачає оперативний і прагматичний підхід до організації освіти упродовж життя на рівні громади міста. І це не абстрактна теорія, адже за умови наявності політичної волі у влади міста і бажання побудувати місто, що навчається, їй потрібен чіткий і доступний інструментарій для визначення прогресу на цьому шляху. Проаналізовано зміст Основних характеристик Глобальної мережі ЮНЕСКО міст, що навчаються, як рамкового документу, в якому представлені ключові риси міст, що навчаються, та пропонується контрольний перелік дій щодо активізації та оцінки прогресу на шляху розбудови міста, що навчається. Важливість цього документу полягає у розумінні того факту, що побудова міста, що навчається, $\epsilon$ неперервним процесом, і не існує тієї межі, досягнувши якої, місто отримало б бажаний статус. При цьому існують об'єктивні ознаки міста, що навчається, і вони стосуються більше того, що місто робить на цьому шля$\mathrm{xy,} \mathrm{а} \mathrm{не} \mathrm{того,} \mathrm{яким} \mathrm{воно} є$.

Ключові слова: суспільства знання, розвиток людського потенціалу, освіта дорослих, формальна і неформальна освіта дорослих, місто, що навчається, регіон, що навчається, Глобальна мережа ЮНЕСКО міст, що навчаються, основні характеристики.

Submitted on March, 22, 2017

UDC: $378: 372.881 .1$

DOI: https://doi.org/10.24195/2414-4665-2017-4-14

Olha Bihun,
Doctor of Philology, associate professor, Department of French Philology, Vasyl Stefanyk Precarpathian National University, 57, Shevchenko Str., Ivano-Frankivsk, Ukraine

\title{
FRENCH AS A SECOND/THIRD FOREIGN LANGUAGE IN THE CONTEXT OF MULTILINGUAL COMPETENCE OF PHILOLOGY STUDENTS
}

Over the last decades one can observe extensive research on the theory of second or third foreign language teaching. Many works are dedicated to foreign language teaching based on the languages of national groups or teaching two foreign languages through their sequential acquisition or simultaneous learning the languages of the same language group. The aim of the article is to analyse the main methods of teaching a second/third foreign language, to specify their general theoretical and practical value in the processes of the development of multilingual competence of philology students. The factors of second language teaching such as the typological comparison of language phenomena; the phonetic, grammar, lexical, syntactic, semantic, morphological transferences were taken into account. The role of the latest methodical practices, such the Internet as an instrument for the organisation of distance learning was highlighted. The experience of foreign language teaching, in particular French, shows that the process of a second foreign language acquisition is a multiaspectual phenomenon which consists of many interrelated factors: linguistic, psychological, sociological and others. The efficiency of foreign language learning depends on the combination of the following factors: the effectiveness of principal methods of teaching, an adequate assessment of the target audience and its requirements for language acquisition, positive psychological mood, students' motivation. Multilingual education results in achieving basic multilingual competence that allows to consider both the alternative way of learning the language and the way to get specific knowledge, to join the values of the world culture and to develop social communicative abilities of a personality.

Keywords: multilingualism, competence, motivation, methods, foreign languages.

\section{Introduction}

Regarding general approaches to the issue of language acquisition in Europe, a strategic approach to language policy is multilingualism considering that every European should learn three or more foreign languages
(FL). Scientists are convinced that the use of several languages enriches a person not only with extensive knowledge of other cultures, but also with the possibility for understanding and being tolerant towards the representatives of other countries. After the fall of the Berlin 
Wall Europe and the whole world have absolutely changed not only in the sphere of international politics but concerning cultural diversity. The linguistic situation in the countries of the European Union attests to multilingualism of Europeans. Thus, more than half of Europeans $(54 \%)$ know at least one FL and a quarter of them have a good command of two more languages except their native one [11].

Over the last decades one can observe extensive research on the theory of second or third foreign language teaching (FLT). Many works are devoted to FLT based on the languages of national groups or teaching two foreign languages through their sequential acquisition $[1 ; 9 ; 12$; 13]. There are works that concern the issues of teaching several foreign languages simultaneously $[6 ; 12]$ or simultaneous learning the languages of the same language group as in the Klein and Stegmann study [10]. The experience of FLT, in particular French, shows that the process of a SFL acquisition is a multiaspectual phenomenon which consists of many interrelated factors: linguistic, psychological, sociological and others. We believe that the efficiency of foreign language learning depends on the combination of the following factors: the effectiveness of principal methods of teaching, an adequate assessment of the target audience and its requirements for language acquisition, positive psychological mood, students' motivation.

The aim of the article is to analyse the main methods of teaching second/third FL, to specify their general theoretical and practical value in the processes of the development of multilingual competence of philology students.

\section{Research methods}

In order to specify the theoretical bases of the study, we used comparative, cross-cultural and crossdisciplinary methods, systematisation of scientific literature on the studied issue.

\section{Discussion}

The communicative function is definitely the main function of a language. The ability to communicate is mainly defined as the ability to use a language under reallife conditions and to perform particular functions and speech acts. The Chomsky's interpretation of the term "competence" should be mentioned here. By competence, the scientist means the abstract and hidden representation of language knowledge held inside our minds, with its potential to create and understand original utterances in a given language [4].

In an attempt to identify the linguistic capacity of multilingual speakers, Cenoz and Genesee proposed that multilingual competence should involve using "several languages appropriately and effectively for communication in oral and written language" [3, 17]. However, such a formulation does not describe the exact level of language proficiency needed for a multilingual speaker. Defining multilingual competence is a complex and difficult task, and researchers have not agreed upon a single explanation yet. Despite the disagreement on the conceptualisation of multilingual competence, researchers have acknowledged that multilingual competence is distinctly marked from that of monolingual speakers and that multilingual competence should not be assessed against that of monolingual speakers [17].

In the course of Methods of Foreign Language Teaching in the Foreign Languages Departments at universities the notion "a second foreign language" (SFL) means that a student has already studied at least one FL and it is English as a rule. Moreover, it is not important in what chronological order French is learnt - as a second language or a third one. Each next language is considered a SFL.

The practice of SFL teaching at universities shows that negative psychological mood is the main barrier to learning a language, as English is traditionally considered easier in comparison with French or German; English being the most widespread language in the world requires more attention than SFL; French is considered to be a very difficult language because of those grammatical phenomena which do not exist in English and cause difficulties especially at the initial stage of its acquisition.

The strategy of SFL involves the condition of active learning process and the fact that the teaching materials should be compatible with the learners' maturational level. It should be taken into account while explaining, for instance, grammar material, encouraging students to contemplate, analyse, compare, hypothesise, find regularities, and discuss results. The students will become more responsible for the learning process; it will make the use of interactive forms of work in a lesson effective. From the experience of first FL students have their own strategy to memorise lexical units which they use for the SFL which they learn.

As a rule, for learning a second language less time is allocated in the curricula compared to a first one. It means that the pace of a lesson should be faster (more teaching materials for a lesson, shorter explanations, more intensive work with exercises). The comparison and discussion of linguistic phenomena similar in both languages also contribute to it.

While learning the first FL, students acquire some skills in performing certain types of activities and have some experience which can be broadened and used during second language acquisition. That is why a French teacher should know what teaching forms and methods were used at English or German lessons. Tasks and exercises should be focused first of all on the comparison and discussion of the similarities and differences in order to find bonds between a mother tongue, the first and second foreign languages. Conscious use of acquired knowledge in English during the learning of French as SFL means the understanding of a new element of a language (a word or a sentence structure), using the experience of recognising a definite phenomenon in English.

The connection between the second and the first foreign languages goes beyond the linguistic aspect. The taking it into account is important for increasing the effectiveness of SFL teaching. In the process of first FL acqui- 
sition students master their skills dealing with its linguistic material - phonetic, graphic, orthographic, mnemotechnic skills working with dictionaries, self-control techniques, etc. Some of these skills and techniques are significant for using teaching materials of SFL, others interfere. The effectiveness of SFL teaching in most cases depends on how a teacher can predict the difficulties students can face under the influence of interferences, and if they appear, he/she should know how to overcome them. For example, one of the difficulties is the pronunciation of a French sound / $\mathrm{v} /$ for the students who have assimilated the bilabial articulation of an English sound /w/, another difficulty is the palatalisation of a French sound $/ 1 /$, etc.

The effectiveness of SFL teaching depends also on how competently a teacher uses the transfer of skills and techniques, earlier acquired by the students in the course of the first foreign language learning. A proper recognition of interference and positive application of skills and techniques of work to linguistic material is a serious factor of the efficiency of SFL teaching.

The comparison of forms and meanings of lexical units and grammatical phenomena that belong to different languages is an important factor of the realisation of this competence. Such comparison illustrates the evolution of languages, their grammatical forms and meanings, the semantic change of a word, their pronunciation and orthography, attests a close connection between the evolution of a language and the social and cultural history of a society. The main thing is that they encourage learners' ideas about a language as a social phenomenon, about national peculiarities of languages, regularities of their development and relations.

The study of psychology of memory shows that the new information is well memorised when in our consciousness it can be associated with something already known. In language acquisition, first of all, it concerns studying vocabulary: learning new words by cramming them without any context is ineffective. Among timetested methods the use of authentic texts should be mentioned. The experience shows that for the realisation of a communicative approach and effective learning of SFL authentic texts that correspond to current realias (authentic innovative materials that illustrate foreign language discourse of analysed French as well as other earlier analysed foreign languages) should be chosen.

It is necessary to start to teach students to perceive a regular every-day FL as soon as possible. It is a common knowledge that the more native speakers (men, women, children) students listen to, the more easily they adjust to the individual manner of conversation. For these aims authentic teaching materials for the textbooks "Vocabulaire en dialogues" by Eveline Siréjols (2008), "Vocabulaire progressif du français" by Claire Miquel (2015), "Grammaire en dialogues" by Claire Miquel (2007), "Grammaire progressive du français" by Maïa Grégoire and Odile Thièvenaz (2005) of CLE International publishing house can be applied. The use of such materials stimulates the development of speech perception that includes not only the perceiving of the whole in the context but also the recognition of lexical and grammatical forms. Although at the initial stage of work with such texts (dialogues) students have some difficulties, however, using lexical support (a printed text) students learn to understand the mother tongue of native speakers and it makes the learning process effective. While choosing educational texts one should take into account not only the content (correspondence to the theme, accessibility), but also its linguistic form (whether there exist some linguistic phenomena which are studied at the moment).

The question of intercultural communication arises in the process of learning several foreign languages. One of the effective methods of teaching intercultural communication is the use of authentic films at the lesson. A film is chosen in such a way that its content arouses interest and stimulates linguistic performance. Besides, a film script can be used as the basis for creating the situations that simulate real linguistic communication at the lesson. The plot of the film should be complete; the duration should not be longer than 15 minutes. A teacher should choose such plots which could be retold by the students at the end of the lesson. The following types of exercises may be used: "Who said that", "Broken telephone", roleplaying games, character description, true or false game, etc. A teacher may suggest that students answer the questions or write the retelling of an episode as a home task. At the second year of teaching French as SFL a video course "EXTR@" Français" (https://ru.pinterest.com /rafaelmedeiros/extr-language-learning-sitcom) can also be used. The plot of 13 episodes of the film uncovers the stories which happen to the youngsters, one of whom is a foreigner and does not understand French well. The presence of changeless characters combines the story lines and assists to concentrate attention. At the end of each part drill exercises are designated for assimilating linguistic examples, phonetic, lexical, grammar materials, the information on country studies. Each episode is relatively independent in terms of its content. It gives the teacher an opportunity to choose the way how to explain the material, an opportunity for gradually adding an excerpt to the teaching process and for the use of separate excerpt depending on a communicative situation.

It is known that considering the peculiarity of interlingual transfer does not solve all the problems of SFL teaching. But its objective recognition, and more important - the proper use contributes to successful resolving of an important problem of SFL teaching - increasing its motivational basis. Sometimes the experience of the preceding learning of a first foreign language shows how difficult it is to acquire a foreign language. It arouses students' disappointment with the ability to acquire SFL under the condition of a limited number of teaching hours. This condition raises a burning issue of intrinsic motivation of foreign languages learning.

Intercultural communication is an adequate social interaction of two or more participants of the communica- 
tive act - representatives of various linguocultures that realise their "otherness", "heterogeneity". However, the necessity of changing the way of thinking, altering the individual worldview basing on a foreign unusual pattern is the main difficulty in a foreign language acquisition, and these difficulties do not lie on the surface and sometimes students or even teachers are not aware of them. Students need to realise that the same notion or a part of reality has different linguistic representations in different languages. Words in different languages that have the same meaning can have different semantic content and reflect different parts of reality. The parts of a mosaic that represents the worldview can be different in size in different languages depending on an amount of conceptual material. The variety of languages reflects the variety of the world. Thus, observing foreign language teachers' working experience, one can see that they acquire the traits of the national culture of the language they teach. The formation of intercultural communicative competence in terms of learning several foreign languages arises from the following components:

- policulturality: accepting new knowledge about foreign culture, respecting other cultures;

- tolerance: an ability to interact with people of other cultures, taking into account their values, an ability to modify one's own behavior in the process of communication with the representatives of other cultures;

- sociability of behavior: an ability to come into contact.

- lingua-socio-cultural experience: an ability to exchange ideas, to listen attentively, to summarise, to draw the attention of an interlocutor.

In the process of learning French as the second or third FL a student expands "his/her individual worldview by means of joining the linguistic worldview of native speakers, their spiritual heritage, specific national ways of reaching intercultural mutual understanding" [6, 47].

Over the last decades the Internet became increasingly widespread in the sphere of FLL in Ukraine as a means of seeking information and access to knowledge (database), as a new form of foreign language communication, as an instrument for the organisation of distance learning. To confirm this opinion, the arguments are as follows:

- the Internet is a rich and diverse resource of authentic information for FL learners and its use is regarded as a stimulus to acquire them. Such material makes students apply their knowledge about the world, speech and the system of languages;

\section{REFERENCES}

1. Baker, C. (1992). Attitudes and Languages. Clevedon: Multilingual Matters [in English].

2. Carrier, M. (1997). ELT online: the rise of the Internet. ELT Journal, 51(3), 279-309 [in English].

3. Cenoz, J., \& Genesee, F. (1998). Beyond bilingualism. Multilingualism and multilingual education. Clevedon: Multilingual Matters [in English].
- authentic material on the Internet provides the information on the culture of the country whose language one studies and which usually cannot be found in textbooks. Pedagogical theories concern the importance of the integration of the culture of the language which is acquired during foreign language lessons as the understanding of the culture of a language which is learned can deepen the understanding of the language itself and therefore increase students' motivation for its learning [8; 14; $18]$;

- Internet resources encourage students to join authentic projects and to write to a real audience of native speakers or those who learn the same foreign language and this is different from the written tasks given by a teacher;

- the Internet contains an enormous amount of visual materials that serve as an additional means of acknowledged and successful learning. The attractive visual presentation stimulates many students while the Internet is an essential teaching resource which presents information in the form of texts, sounds and visual images. The study shows that students are ready to spend more time reading or listening to long audio fragments from the Internet than from other resources $[2 ; 7 ; 15]$.

Thus, the use of the Internet broadens the variety of communicative situations, increases students' motivation, and allows them to effectively apply acquired knowledge and skills to solve real communicative tasks.

\section{Conclusions}

The main aim of contemporary higher education is to prepare students for interaction with multilingual and polycultural world. To achieve this aim, universities have the task to teach students several foreign languages. The appearance of this task in the sphere of education has caused the necessity of intercultural communication. Today, when interactive and computer technologies are developing, independent learning of several foreign languages becomes more real. Grasping these opportunities allows students to acquire knowledge, to form and develop skills of foreign competence themselves.

Multilingual education results in achieving basic multilingual competence that allows to consider both the alternative way of learning the language and the way to get specific knowledge, to join the values of the world culture and to develop social communicative abilities of a personality. Yet second/third foreign language teaching methods need more study.

4. Chomsky, N. (1965). Aspects of the Theory of Syntax. Cambridge, MA: MIT Press [in English].

5. Cicurel, F. (2005). La flexibilité communicative: un atout pour la construction de l'agir enseignant [Communicative flexibility: an asset for the construction of the teaching act]. Le français dans le monde: Recherches et applications (Les interactions en classe) - French in the world: Research and applications (Classroom interac- 
tions), (pp. 145-164). Retrieved from: http://www.ilpga.univ-paris3.fr/pages-

personnelles/francine-cicurel/articles/f2.pdf [in French].

6. Coste, D. (2006). De la classe bilingue à l'éducation plurilingue [From bilingual to polylingual education.]. Le français dans le monde - French in the world, mai-juin, 345. Retrieved from: http://www.fdlm.org/fle/article/345/bilingue.php [in French].

7. Cronin, M., \& Myers, S. (1997). The effects of visuals versus no visuals on learning outcomes from Interactive multimedia instruction. Journal of Computing in Higher Education Spring, 8(2), 46-71 [in English].

8. Gilmore, A. (2007). Authentic materials and authenticity in foreign language learning. Language Teaching, 40 (2), 97-118 [in English].

9. Isaacs, T., \&Trofimovich, P. (2016). Second Language Pronunciation Assessment. Clevedon: Multilingual Matters [in English].

10. Klein, H. G., \& Stegmann, T. D. (2000). EroComRom - Die Sieben Siebe: Romanische Sprachen sofort lesen können [EroComRom - The Seven Sieves: Romanic languages can be read immediately]. Frankfurct: Fachbuch [in German].

11. Les Européens et leurs langues: rapport [Europeans and their languages: report]. (2012), Eurobaromètre special 386 . Retrieved from:

\section{ЛІТЕРАТУРА}

1. Baker C. Attitudes and Languages / C. Baker. Clevedon: Multilingual Matters, 1992. - 173 p.

2. Carrier M. ELT online: the rise of the Internet / M. Carrier // ELT Journal. - 1997. - № 51(3). - PP. 279309.

3. Cenoz J. Beyond bilingualism. Multilingualism and multilingual education // J. Cenoz, F. Genesee. Clevedon: Multilingual Matters, 1998. - 288 p.

4. Chomsky N. Aspects of the Theory of Syntax / N. Chomsky. - Cambridge, MA: MIT Press, 1965. $248 \mathrm{p}$.

5. Cicurel F. La flexibilité communicative: un atout pour la construction de l'agir enseignant / F. Cicurel // Le français dans le monde: Recherches et applications (Les interactions en classe). - 2005. - №7 (juillet). - PP. 145164.

6. Coste D. De la classe bilingue à l'éducation plurilingue / D. Coste // Le français dans le monde. - 2006. №6 (mai-juin). - P. 345.

7. Cronin M. The effects of visuals versus no visuals on learning outcomes from Interactive multimedia instruction / M. Cronin, S. Myers // Journal of Computing in Higher Education Spring. - 1997. - №8 (2). - PP. 4671.

8. Gilmore A. Authentic materials and authenticity in foreign language learning / A. Gilmore // Language Teaching. - 2007. - № 40 (2). - PP. 97-118. http://ec.europa.eu/public_opinion/archives/ebs/ebs_386_ fr.pdf [in French].

12. Littlewood, W. (1984). Foreign and Second Language Learning. Cambridge, New York: Cambridge University Press [in English].

13. Mitchell, R., \& Myles, F. (2004). Second Language Learning Theories ( $2^{\text {nd }}$ ed.), London: Hodder Arnold [in English].

14. Peacock, M. (1997). The effect of authentic materials on the motivation of EFL learners. ELT Journal, 51 (2), 144-156 [in English].

15. Reynolds, R. (2010). Museum audios for design students: Auditory wallpaper or effective learning support? Art, Design \& Communication in Higher Education, 9 (2), 151-166 [in English].

16. Richards, J. C., \& Rodgers, T. S. (2001). Approaches and Methods in Languages Teaching. ( $2^{\text {nd }}$ ed.). Cambridge, New York: Cambridge University Press [in English].

17. Saville-Troike, M. (2006). Introducing Second Language Acquisition. Cambridge, New York: Cambridge University Press [in English].

18. Wilcox, B., Morrison, T., \& Oaks, D. (1999). Computer corpora and authentic texts: Toward more effective language teaching. Reading Research and Instruction, 38(4), 415-42 [in English].

9. Isaacs T. Second Language Pronunciation Assessment / T. Isaacs, P. Trofimovich. - Clevedon: Multilingual Matters, 2016. -288 p.

10. Klein H. G. EroComRom - Die Sieben Siebe: Romanische Sprachen sofort lesen können / H. G. Klein, T. D. Stegmann. - Frankfurct: Fachbuch, 2000. - 274 p.

11. Les Européens et leurs langues: rapport [Електронний pecypc]. - Eurobaromètre special, 2012. - - Режим доступу: http://ec.europa.eu/public_opinion/archives/ebs/ebs_386_ fr.pdf

12. Littlewood W. Foreign and Second Language Learning / W. Littlewood. - Cambridge; New York: Cambridge University Press, 1984. - 122 p.

13. Mitchell R. Second Language Learning Theories / R. Mitchell, F. Myles. - London: Hodder Arnold, 2004. $-316 \mathrm{p}$.

14. Peacock M. The effect of authentic materials on the motivation of EFL learners / M. Peacock // ELT Journal. - 1997. - №51 (2). - PP. 144-156.

15. Reynolds R. Museum audios for design students: Auditory wallpaper or effective learning support? / R. Reynolds // Art, Design \& Communication in Higher Education. - 2010. - №9 (2). - PP. 151-166.

16. Richards J. C. Approaches and Methods in Languages Teaching / J. C. Richards, T. S. Rodgers. $-2^{\text {nd }}$ ed. - Cambridge; New York: Cambridge University Press, 2001. -268 p. 
17. Saville-Troike M. Introducing Second Language Acquisition / M. Saville-Troike. - Cambridge; New York: Cambridge University Press, 2006. - 206 p.
18. Wilcox B. Computer corpora and authentic texts: Toward more effective language teaching / B. Wilcox, T. Morrison \& D. Oaks // Reading Research and Instruction. - 1999. - № 38(4). - PP. 415-423.

Ольга Альбертівна Бігун, доктор філологічних наук, дочент кафедри франиузької філології, Прикарпатський національний університет імені Василя Стефаника, м. Івано-Франківськ, вул. Шевченка, 57, Украӥна

\section{ФРАНЦУЗЬКА ЯК ДРУГА/ТРЕТЯ ІНОЗЕМНА МОВА В КОНТЕКСТІ МУЛЬТИЛІНГВАЛЬНОЇ КОМПЕТЕНЦІЇ СТУДЕНТА-ФІЛОЛОГА}

В останні десятиліття спостерігається активне дослідження теорії навчання другої/третьої іноземної мови. Багато робіт присвячено питанням навчання іноземних мова на базі мов національних груп або двом іноземним мовам через їх послідовне засвоєння. 3'являються також праці, що стосуються питань навчання багатомовності за допомогою одночасного навчання кількох іноземних мова або одночасне вивчення мов однієї мовної групи. Метою статті є аналіз основних методів навчання кількох іноземних мов, з'ясовується їх загальнотеоретичний та практичний потенціал у процесах формування мультилінгвальної компетенції студентів-філологів. Увагу зосереджено на основних прийомах викладання другої/третьої іноземної мови, серед яких типологічне зіставлення мов, фонетична, граматична, лексична, синтаксична, семантична, морфологічна інтерференція. Окремо розглянуто роль IT технологій для дистанційного навчання. Досвід викладання другої іноземної мови, а саме французької, свідчить про те, що процес оволодіння другою іноземною мовою є багатоаспектним явищем, яке складається з багатьох взаємопов'язаних факторів: лінгвістичних, психологічних, соціологічних та ін. Необхідно враховувати, що результативність вивчення іноземної мови залежить від сукупності таких факторів, як ефективність провідної методики викладання, адекватна оцінка цільової аудиторії та ії потреб щодо вивчення іноземної мови, позитивний психологічний настрій, мотивація студентів. Результатом мультилінгвальної освіти $\epsilon$ досягнення базової мультилінгвальної компетенції, що дозволяє розглядати ії не тільки в якості альтернативного шляху вивчення мови, але й як шлях опанування спеціальних знань, прилучення до цінностей світової культури та розвитку соціально-комунікативних здібностей особистості.

Ключові слова: мультилінгвальність, компетенція, мотивація, методи, іноземні мови.

Submitted on March, 23, 2017 